About Our Cover

\title{
University of Florida's Horticultural Sciences Department: A New Program with Technology for the Future
}

The Univ. of Florida (UF), established in 1906, is Florida's land-grant university and oldest and largest institution of higher education. UF, located on 810 ha-most within Gainesville's urban area (population 85,000), offers excellent classroom, laboratory, and field facilities for a wide range of academic programs. UF is a member of the Association of American Universities, the nation's most prestigious higher education organization, and ranks among the nation's top three universities in the number of academic programs available at a single campus. UF offers 52 undergraduate programs, which encompass 114 majors. Graduate programs offer MS and $\mathrm{PhD}$ degrees in 123 and 76 fields, respectively.

UF is divided into 20 colleges, including the College of Agriculture, which consists of the Horticultural Sciences Dept. and 19 other departments. The College of Agriculture is part of the university's Institute of Food and Agricultural Sciences (IFAS), a statewide organization committed to educating students and strengthening Florida's agricultural industry through extension and research programs. Research is conducted by IFAS in Gainesville and at 22 other research centers across the state. Extension programs, which provide an informal education in agriculture and related topics, originate in the departments and are conducted in all 67 counties.

The university's more than 35,000 students are a cosmopolitan group-drawn from every county in the state, every state in the nation, and more than 100 foreign countries. Ninety percent of the university's freshmen earned admission test scores above the national average. Today, UF enrollment includes the fifth highest number of national merit scholars attending a U.S. public university.

No horticulture department existed during the university's early years; therefore, the faculty was assigned to either the experiment station, extension service, or College of $\mathrm{Ag}$ riculture. This loose organization changed in 1955, when the new agricultural center, McCarty Hall, was completed and W.M. Fifield was appointed provost for agriculture.

The first Dept. of Horticulture was formed in 1955, with Walter Reuther (former ASHS president) as head. When he resigned less than

Received for publication 23 Dec. 1992. Accepted for publication 28 Jan. 1993. The cost of publishing this paper was defrayed in part by the payment of page charges. Under postal regulations, this paper therefore must he hereby marked advertisement solely to indicate this fact.

Cover photos courtesy of NASA and the Florida Dept. of Citrus. Cover concept, George Hochmuth; cover design, Norm Childers.
1 year later, the department was divided into four departments: Fruit Crops (J.W. Sites, head); Vegetable Crops (F.S. Jamison, head; former ASHS president); Ornamental Horticulture (E.W. McElwee, head); and Food Technology (Ray Demison, head). The horticulture farm (purchased in 1956 and located $14 \mathrm{~km}$ from campus) was used by all departments for research. In 1957, the Fruit Crops and Vegetable Crops departments each established its first $\mathrm{PhD}$ program, and the first graduate degree was awarded in 1958. A.H. Krezdorn (former ASHS president) replaced Sites as head of the Fruit Crops Dept. in 1960. Sites became associate director of the experiment station. Fifield retired as provost in 1962 and was replaced by E.T. York. In 1964, York reorganized the college, experiment station, extension service, and Forestry Dept. into the Inst. of Food and Agricultural Sciences and stipulated that all department heads be designated "chairmen" (1966). The Vegetable Crops Dept. has since been chaired by V.F. Nettles, G.A. Marlowe, J.F. Kelly (former ASHS president), C.B. Hall, D.N. Maynard, and D.J. Cantliffe, and the Fruit Crops Dept. by R.H. Biggs, M.J. Burke, W.J. Wiltbank, and L.K. Jackson. In 1973, the departments' graduate curricula were combined as horticultural sciences. The horticultural sciences and plant pathology building was first occupied in 1979 and renamed Willard M. Fifield Hall in 1984.

The 1980s was a decade of monumental change in both departments. Faculty members were added and programs were shifted. The applied sciences yielded to the basics, a change that required expensive laboratories and gigantic grants. The "freeze of the century" in 1983 forced the citrus industry to relocate to southern Florida and helped vegetable receipts pass the billion dollar hump.

In Dec. 1991, the late G.L. Zachariah, vice president for agriculture, merged the Fruit Crops and Vegetable Crops departments into a single Horticultural Sciences Dept. and appointed Cantliffe as chairman. Thus, one department, allied with its satellite research and education centers and supported by a combined fruit and vegetable industry exceeding $\$ 3.8$ billion in value, began a new era in agriculture in Florida.

Students in the Horticultural Sciences Dept. can earn BS, MA, MS, and $\mathrm{PhD}$ degrees in the horticultural sciences, and MS and $\mathrm{PhD}$ degrees in plant molecular and cellular biology. Courses are taught at Gainesville and several research and education centers. Graduate students and their supervisory committees design unique study programs that are tailored to the student's professional interests and goals.

The departmental merger created what is probably the largest horticulture department at any university in the world. A total of 80 faculty members is located at the main campus in Gainesville or at research and education centers throughout the state. This faculty is responsible for developing, evaluating, and disseminating knowledge and information necessary to support the extremely diverse fruit and vegetable industries of Florida, and the nation. Their expertise covers breeding and genetics, crop production and plant nutrition, molecular and physiological genetics, physiology and biochemistry, postharvest biology and technology, and weed science.

The Horticultural Sciences Dept. has active breeding programs in beans, carrot, celery, cucurbits, lettuce, pepper, sweet corn, tomato, blueberry, grape, peach, and strawberry. Most of these breeding programs are headquartered at research centers in the primary production region of each species. The Everglades Research and Education Center has celery, lettuce, pepper, and sweet com breeding programs. The tomato and strawberry breeding programs are headquartered at the Gulf Coast Research and Education Centers in Bradenton and Dover, respectively. The cucurbit breeding program, which emphasizes watermelon improvement but also includes melon and squash, is housed at the Central Florida Research and Education Center in Leesburg.

Blueberry and peach breeding programs are conducted at Gainesville, citrus at Lake Alfred and Gainesville, grapes at Leesburg, tropical fruits at Homestead, and other deciduous fruits and nuts at Gainesville. The deciduous fruit improvement programs provide cultivars for small-farm industries in Florida. These cultivars also are grown extensively in subtropical climates in more than 80 countries and territories. Peach and nectarine cultivars that have maximum flavor and flesh firm enough to permit harvest at the tree-ripe stage are being developed. The first Japanese-type plums for subtropical climates are planned for release in 3 years. Self-fertile blueberries resistant to several diseases and insects are on the horizon. Tristeza-resistant citrus cultivars have been developed through biotechnology. Breeding programs to improve citrus fruit quality, scion cold hardiness, and soil adaptation and pest resistance in rootstock are progressing.

Many cultivar releases have dominated their respective industries in Florida and proven useful as germplasm in national and international breeding programs. The horticultural sciences breeding programs traditionally have taken an interdisciplinary approach to germplasm development. Close relationships exist between breeders and their cooperators in entomology, horticulture, molecular biology, plant nutrition, plant pathology, and plant physiology. Because many of the breeding programs are located at specialized off-campus centers, cooperative relationships are a natural consequence of an interdisciplinary faculty. This type of research environment is ideal for graduate studies in plant breeding. Students are exposed to important research

(continued on p. 74) 
(continued from inside front cover)

issues at the basic and applied levels across diverse disciplines.

The department also emphasizes biotechnology research, which is supported by the resources of the Interdisciplinary Center for Biotechnological Research. Graduate-level teaching includes the curriculum of the plant molecular and cellular biology program. Within the department, 11 positions are dedicated to biotechnology research and education, while three positions-the C.V. Griffin Endowed Chair, the Lyle C. Dickman Endowed Chair, and a professorship in postharvest physiology-will be filled by experts in molecular biology. Biotechnology faculty are researching the mechanisms by which plant genes are expressed, mechanisms and vectors that allow foreign DNA incorporation into plant cells, agriculturally important genes, and tissue culture techniques that allow plant regeneration from single cells. Specific research areas include regulatory genes controlling seed development, genes involved in starch biosynthesis, chromatin structure, gene regulation and transacting regulatory factors, low-temperature tolerance, tagging genes for disease resistance, linkage map construction, cytoplasmic male sterility, activation of metal binding proteins, chloroplast biogenesis, transformation technologies, and photosynthetic product translocation and metabolism. The crops used in these studies include bean, citrus, corn, grape, lettuce, muskmelon, sweetpotato, tomato, and watermelon.

Department faculty also conduct extensive research on the diverse aspects of basic and whole-plant physiology. Environmental physiology research includes programs in developmental and physiological responses of tree and vegetable crops to flooding, freezing, and chilling, as well as winter chilling and photoperiodic effects on dormancy. Carbohydrate and nitrogen metabolism studies include projects on whole-plant source-sink relations and carbohydrate/nitrogen roles in reproductive development, and basic research on starch biosynthesis regulation, sugar transport and partitioning mechanisms, control of tissue carbohydrate and nitrogen accumulation, sugar-modulated gene expression, and cell wall metabolism. Seed physiology research, another major focus of the department, involves seed development and maturation regulation, seed dormancy, and synthetic seed production.

Since $\approx 75 \%$ of Florida-grown produce is shipped outside the state, the overall goal of the postharvest physiology research program is to understand the basic processes that maintain postharvest quality, and to develop and apply relevant technologies to harvesting, handling, distributing, and exporting produce. This broad-based program encompasses diverse crops from temperate, subtropical, and tropical environments. Examples of recent research illustrate this diversity: the role of cellulase and pectinases in avocado fruit softening, residual effects of low- $\mathrm{O}_{2}$ storage on bell pepper respiratory metabolism, postharvest treatments to reduce vascular streaking in cassava, efficacy of chlorine washes on Florida tomato pathogens, computer modeling of modified-atmosphere packaging for blueberries and strawberries, impact thresholds for bell pepper and tomato during handling, storage acid metabolism in citrus fruits, and ethylene responsiveness and climacteric status of carambola fruit.

Crop losses due to weeds, combined with the cost of weed control, represent a significant loss of income for Florida's horticultural producers. Since many horticultural production areas are near some of Florida's most environmentally sensitive land, the department's weed science research emphasizes ways to lessen the potentially negative impact of weed control. Weed scientists have adopted an integrated weed management philosophy to reduce the use of synthetic chemicals. Research to establish critical periods for weed control and tolerable levels of weed interference in crops has provided the ecological foundation for studies on specific weed problems. Applied research involving cultural control methods, such as mulches and tillage, is augmented by basic research involving herbicides that are potentially less harmful to the environment. This research involves environmental fate, physiological plant-herbicide interactions, and herbicide evaluation. As part of an interdisciplinary team, weed scientists are developing crop cultivars that are resistant to environmentally safe herbicides. Biological weed control that emphasizes the use of plant pathogens as bioherbicides is a major interest. An international effort has been initiated to develop a bioherbicide for various nutsedge species, one of the worst weeds, and other weeds that are problems for Florida growers. By forming interdisciplinary teams, our researchers have tapped the experience of leading world experts working on biological weed control in Florida.

Florida soils include sandy Entisols (central ridge), Spodosols (flatwoods), limestone (rockland), and organic Histosols (muck). Vegetables are produced on each of these soils, while citrus is grown on all but the Histosols. Each soil has presented challenges to Florida researchers to develop nutrient and water management programs that optimize horticultural crop production while minimizing environmental impact. Fertilization practices in Florida are based on a crop nutrient requirement (CNR) concept that involves a calibrated soil test to determine fertilizer needs. Nutrients are supplied to makeup the difference between the CNR and the amount of nutrients supplied from the nonfertilized soil. Researchers from at least five academic departments and more than 20 research centers throughout Florida have contributed to our modem fertilization recommendations. Production techniques using polyethylene mulch, split fertilizer applications, controlled-release fertilizers, and fertigation have been developed and refined and are now part of our extension recommendations. Florida's humidity, leachable soils, and close water tables make it imperative for our fertilization programs to include irrigation management. Many researchers are determining water requirements of specific horticultural crops, especially tomato and strawberry. Determining crop water requirements and developing efficient irrigation methods will allow horticulture to share the state's water resources with an ever-increasing population. Crop specialists, soil scientists, agricultural engineers, and extension personnel are designing fertilization and irrigation programs that will prove profitable for the horticultural industry and protect Florida's environment and groundwater.

Weather research at Gainesville deals with hurricanes, freezes, and severe thunderstorms that are a significant risk to horticultural production in the state's varied climates. Recent severe freezes helped educate workers in the use of cold protection methodology. Research on heating and wind machines began in the 1950s. Later, foam, fog, and irrigation techniques influenced cold and frost protection technology around the globe. Funding from the National Aeronautics and Space Administration has supported a project to create observed, and forecasted thermal maps during freezes. Under cloudless conditions, color images show temperature distributions throughout the state. When clouds are present, the cloud top temperatures indicate cloud height during convective showers beneath the clouds. These thermal maps have been combined with real-time radar images in the same computercontrolled acquisition system. Students working on this program receive ideal preparation in computer graphics and microclimate modification and an appreciation of how plants react to stress.

An Organic Gardening Research and Education Park was established to serve as a database development and collection resource for teaching and extension programs. A model garden, maintained year-round using the best recommended organic practices, serves as a focal point for other activities, which include a garden of standard and unusual vegetables, a soil amendment and fertilizer test area, a cultural practice test site, and student gardens. An organic vegetable gardening course attracts students from colleges other than agriculture and provides hands-on experience. Other current-interest topics, such as use of composted yard wastes, organic transplant production, and pest control strategies, are practiced in research and extension plots. An annual field day highlights facility activities and draws an audience from across the state.

These research, teaching, and extension activities illustrate the breadth of the horticultural sciences program at the Univ. of Florida. The basic theme of our program, illustrated in our cover photo, is to include science and technology in modem horticultural crop production. The Horticultural Sciences Dept. faculty, staff, and students are the heart of the sustained development and success of Florida's vast fruit and vegetable industries.

The Faculty Horticultural Sciences Dept. Univ. of Florida

Gainesville 